\title{
Effects of Converting Enzyme Inhibitor (SQ 20881) on Changes in Blood Pressure and Plasma Aldosterone Induced by Angiotensin I or Acute Hemorrhage in Rabbits
}

Ikuo Saito, M.D., Toyohisa Eguahi, M.D., Ryuichi Nakamura, M.D., Jiro Misumi, M.D., Kazuoki Kondo, M.D., and Takao SaruTA, M.D.

\section{SUMmary}

The effects of angiotensin converting enzyme inhibitor (CEI) upon blood pressure and plasma aldosterone (PA) were studied in rabbits with a simultaneous infusion of angiotensin I (ANG I) or with hemorrhagic hypotension.

Pretreatment with CEI (SQ 20881), $1.0 \mathrm{mg} / \mathrm{Kg}$, inhibited the effects of infused ANG I, $30 \mathrm{ng} / \mathrm{Kg} / \mathrm{min}$, upon PA and blood pressure at $30 \mathrm{~min}$ of the infusion, but the inhibition on PA was not significant at $60 \mathrm{~min}$ of the infusion. The same dose of CEI was ineffective in blocking the effect of $100 \mathrm{ng} / \mathrm{Kg} / \mathrm{min}$ of ANG I on PA and blood pressure even at $30 \mathrm{~min}$ of the infusion.

In rabbits with hemorrhagic hypotension, injection of CEI resulted in the decrement in blood pressure, whereas no decrement in blood pressure was observed in normal control rabbits.

This study suggests that CEI exerts it's effect in part by inhibiting conversion of ANG I to angiotensin II (ANG II), but this can't exclude other mechanisms.

\section{Additional Indexing Words :}

Plasma renin activity

T $\mathrm{N}$ recent years, 2 kinds of inhibitors of the renin-angiotensin system have been found as useful in the diagnosis and management of hypertensive diseases. ${ }^{1)}$ One class of agent is an inhibitor of the enzyme that is responsible for the conversion of ANG I to ANG II. The inhibition of pressor response to ANG I by CEI was well established, ${ }^{21,3)}$ while the effect of CEI upon the steroidogenic response induced by ANG I has not been well documented. Although it is considered that ANG I possesses it's biological activity after the conversion to ANG II, ${ }^{4}$ there is a possibility that ANG I per se does have biological activity in stimulating steroidogenesis as shown in the in vitro

From the Department of Internal Medicine, Keio University School of Medicine, Tokyo

Address for reprint: Takao Saruta, M.D., Department of Internal Medicine, Keio University School of Medicine, 35 Shinanomachi, Shinjuku-ku, Tokyo 160, Japan.

Received for publication March 13, 1979. 
experiment with adrenal slices. ${ }^{5)}$ Thus, it would be of interest to study the effect of ANG I on steroidogenesis in animals treated with CEI.

In the present study, the effects of 2 different doses of ANG I (30 ng/Kg/ min and $100 \mathrm{ng} / \mathrm{Kg} / \mathrm{min}$ ) on blood pressure and PA were examined in rabbits with or without pretreatment of CEI, and then the effect of CEI alone upon blood pressure in rabbits with hemorrhagic hypotension was also examined.

\section{Material AND Methods}

Studies were carried out in 18 female rabbits, weighing 2.3 to $3.6 \mathrm{Kg}$. They were fed on a standard laboratory diet and a tap water ad libitum. Under general anesthesia with sodium pentobaribital, $25 \mathrm{mg} / \mathrm{Kg}$, intravenously, femoral artery and vein were cannulated for continuous measurement of blood pressure, collection of blood and the infusion of agents, respectively.

Experiment 1. Effects of ANG I on blood pressure and PA were examined with or without CEI. Following $90 \mathrm{~min}$ of control period, blood was collected for the determination of basal PA. After the first collection of blood, bolus injection of SQ 20881, $1.0 \mathrm{mg} / \mathrm{Kg}$, or saline was performed, and then ANG I, at a dose of $30 \mathrm{ng} / \mathrm{Kg} / \mathrm{min}$ or $100 \mathrm{ng} / \mathrm{Kg} / \mathrm{min}$, was infused for $60 \mathrm{~min}$. Blood was obtained $30 \mathrm{~min}$ after the start of infusion of ANG I and at the end of the infusion. ANG I was obtained from Protein Research Foundation, Osaka, SQ 20881 was obtained from the Squibb Institute for Medical Research, Princeton, New Jersey.

Experiment 2. Effect of SQ 20881 upon blood pressure was studied in 9 rabbits. After the collection of blood for the determination of plasma renin activity (PPA), effect of bolus injection of SQ 20881, 0.5 to $1.0 \mathrm{mg} / \mathrm{Kg}$ upon blood pressure was examined as the control experiment. And then, 40 to $50 \mathrm{ml}$ of blood was withdrawn to stimulate the endogenous renin-angiotensin system and the same procedure as control experiment was done.

Blood pressure was monitored continuously by connecting the femoral arterial catheter to a pressure transducer and a recorder (Nihon Koden Co, Tokyo) and the response to agents is reportcd as a maximal changes.

PA was determined by radioimmunoassay. ${ }^{6}$ ) PRA was measured by the method of Skinner.")

Statistical analysis was carried out using Student's t-test. Values are presented as mean \pm standard error.

\section{Results}

Experiment 1. Effects of the infusion of ANG I at a dose of $30 \mathrm{ng} / \mathrm{Kg} /$ min with or without pretreatment of SQ 20881, $1.0 \mathrm{mg} / \mathrm{Kg}$, were shown in Figs. 1 and 2. Inhibition of a rise in blood pressure and PA by the pretreatment of SQ 20881 was observed at $30 \mathrm{~min}$, but it disappeared at $60 \mathrm{~min}$ of 


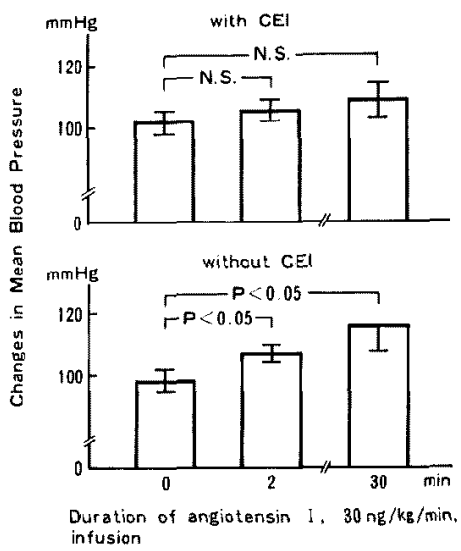

Fig. 1. Effect of $\mathrm{SQ} 20881,1.0 \mathrm{mg} / \mathrm{Kg}$, upon blood pressure changes induced by angiotensin $\mathrm{I}, 30 \mathrm{ng} / \mathrm{Kg} / \mathrm{min}$.

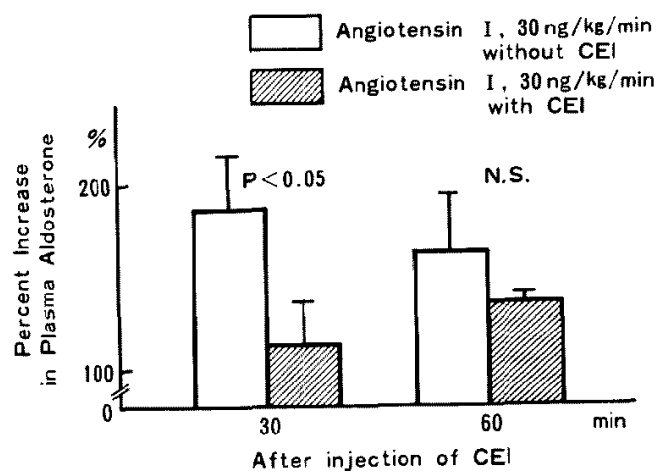

Fig. 2. Effect of $\mathrm{SQ} 20881,1.0 \mathrm{mg} / \mathrm{Kg}$, upon change in plasma aldosterone induced by angiotensin $\mathrm{I}, 30 \mathrm{ng} / \mathrm{Kg} / \mathrm{min}$.

infusion of ANG I. Pretreatment with SQ 20881, $1.0 \mathrm{mg} / \mathrm{Kg}$, was ineffective in inhibiting the rise in blood pressure and PA induced by the infusion of ANG I at a dose of $100 \mathrm{ng} / \mathrm{Kg} / \mathrm{min}$ (Figs. 3 and 4 ).

Experiment 2. Bolus injection of $\mathrm{SQ} 20881$ at a dose of $1.0 \mathrm{mg} / \mathrm{Kg}$ didn't show any significant change in blood pressure in the normal rabbits, on the other hand, a rapid decline in blood pressure was observed in the rabbits with hemorrhagic hypotension (Fig. 5). A relationship between changes in blood pressure induced by the infusion of SQ 20881 and PRA prior to the injection of the inhibitor was significant $(p<0.01)$ (Fig. 6). 


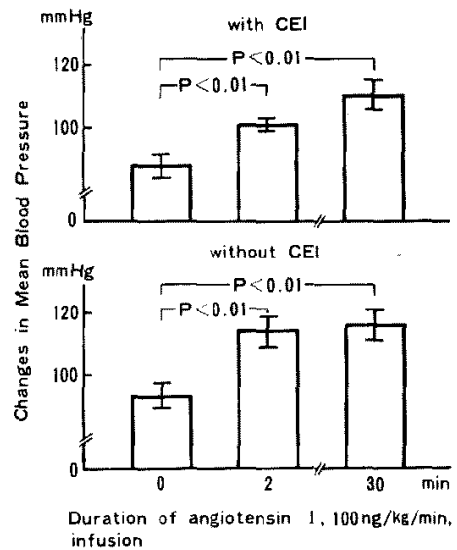

Fig. 3. Effect of SQ 20881, $1.0 \mathrm{mg} / \mathrm{Kg}$, upon blood pressure change induced by angiotensin $\mathrm{I}, 100 \mathrm{ng} / \mathrm{Kg} / \mathrm{min}$.

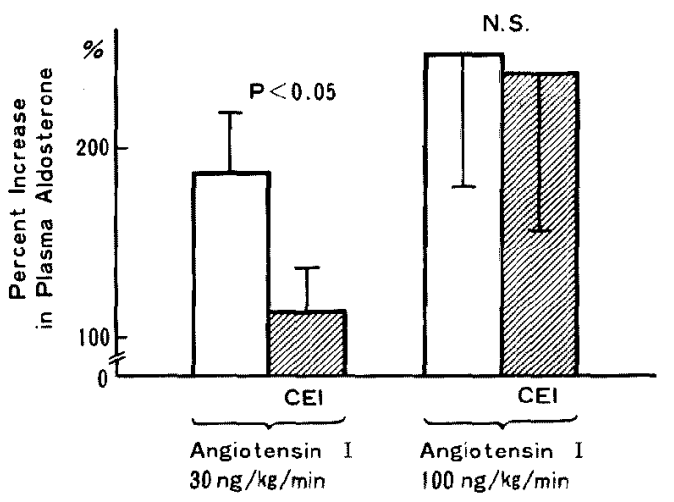

Fig. 4. Effect of SQ 20881, $1.0 \mathrm{mg} / \mathrm{Kg}$, upon plasma aldosterone induced by angiotensin $I, 30 \mathrm{ng} / \mathrm{Kg} / \mathrm{min}$ or $100 \mathrm{ng} / \mathrm{Kg} / \mathrm{min}$, at $30 \mathrm{~min}$ of infusion.

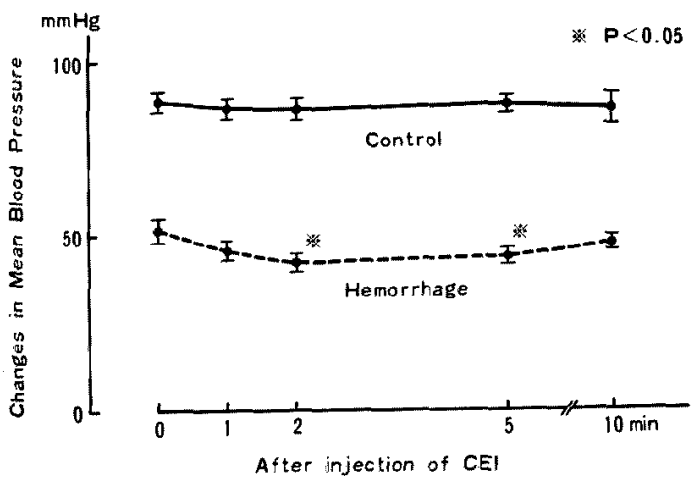

Fig. 5. Effect of $\mathrm{SQ} \mathrm{20881,} 1.0 \mathrm{mg} / \mathrm{Kg}$, upon blood pressure in rabbits with or without hemorrhagic hypotension. 


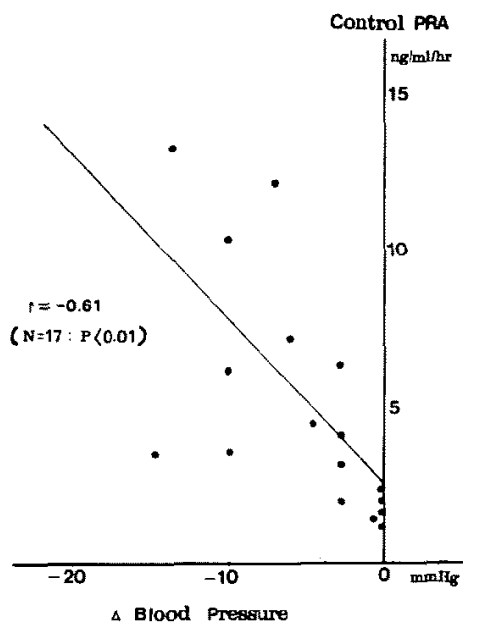

Fig. 6. Relation between control plasma renin activity and changes in blood pressure induced by the injection of SQ 20881, $1.0 \mathrm{mg} / \mathrm{Kg}$.

\section{Discussion}

In the present study, SQ 20881 was utilized as a CEI. Although $1 \mathrm{mg} / \mathrm{Kg}$ of SQ $2088 \mathrm{I}$ is reported to be effective in inhibiting the vasopressor effect of ANG I for $60 \mathrm{~min}$ at least, ${ }^{8}$ ) the inhibition of ANG I-induced steroidogenesis by SQ 20881 disappeared at $60 \mathrm{~min}$ in this study. There are several possible explanations for this discrepancy. One is a direct stimulation by accumulated ANG I to the adrenal glands. Saruta et al ${ }^{5}$ reported that the concentration of ANG I, approximately $1 \mu \mathrm{g} / \mathrm{Gm}$ tissue, stimulated aldosterone production in the beef adrenal slices. Although this dose can be attainable in the in vitro study, it seems unlikely that plasma level of ANG I increased to such a remarkably high concentration during the infusion of ANG I. Another possibility is that accumulated ANG I and/or bradykinin stimulated steroidogenesis via the stimulation of prostaglandins. Blumberg et $\mathrm{al}^{\mathbf{9})}$ found that circulating peptide hormones such as ANG I, ANG II, and bradykinin stimulated the release of prostaglandin $E$ that was one of known stimuli for aldosterone production. ${ }^{10), 11)}$ The third possibility is the accumulation of ANG I that might break through the inhibition by CEI and result in the conversion of ANG I to ANG II.

The results that infusion of high dose of $A N G I(100 \mathrm{ng} / \mathrm{Kg} / \mathrm{min})$ increased in blood pressure and PA with or without pretreatment of SQ 20881 could be also explained by these possibilities.

After the infusion of SQ 20881, no significant change in blood pressure was observed in normal rabbits, but a significant depressor response was 
observed in rabbits with hemorrhagic hypotension. We can speculate about the mechanisms underlying the depressor response as follows. The animals might become angiotensin dependent in the maintenance of blood pressure after hemorrhagic hypotension, ${ }^{12}$ so that inhibition of stimulated reninangiotensin system by CEI might result in depressor response. ${ }^{13)}$ Another possibility is that CEI per se depressed the activity of the sympathetic nervous system $^{14}$ that might be enhanced in the animals with hemorrhagic hypotension. The third possibility is vasodilating effect and natriuretic effect of bradykinin, since CEI might also potentiate the action of bradykinin. ${ }^{15}$ ) Although bradykinin is not only a direct vasodilator but also a stimulus for release of depressor prostaglandin, it is noteworthy that hemodynamic response to $\mathrm{CEI}^{16)}$ is contrasted with that to bradykinin ${ }^{17)}$ or prostaglandin ${ }^{18)}$ that is accompanied with increased heart rate. CEI might evoke the complexed humoral interaction, and unifactorial explanation can account for its. effect.

\section{AckNOWLedGMents}

We thank Miss Yoko Sano for the preparation the manuscript. SQ 20881 was kindly provided by the Squibb Institute for Medical Research, Princeton, New Jersey.

\section{REFERENCES}

1. Davis JO, Freeman RH, Johnson JA, Spielman WS: Agents which block the action of the renin-angiotensin system. Circulat Res 34: 279, 1974

2. Bianchi A, Evans DB, Cobb $M$ et al: Inhibition by $S Q 20881$ of vasopressor response to angiotensin $I$ in conscious animals. Eur $J$ Pharmacol 23: 90, 1973

3. Jaeger P, Ferguson RK, Brunner HR et al: Mechanism of blood pressure reduction by teprotide (SQ 20881) in rats. Kidney Intern 13: 289, 1978

4. Goodfriend TL, Peach MJ: Angiotensin III. Evidence and speculation for its role as an important agonist in the renin-angiotensin system. Circulat Res 36, 37 (suppl I) : 1-38, 1975

5. Saruta T, Cook R, Kaplan NM: Adrenocortical steroidogenesis. Studies on the mechanism of action of angiotensin and electrolytes. J Clin Invest 51:2239, 1972

6. Saito I, Saruta T, Eguchi T et al: Role of angiotensin III in the regulation of blood pressure, plasma aldosterone and plasma renin activity in rabbit. Acta Endocr (kbh) 89: 132, 1978

7. Skinner SL: Improved assay methods for renin concentration and activity in human plasma. Circulat Res 20: 391, 1967

8. Gavras H, Brunner HR, Laragh JH et al: An angiotensin converting enzyme inhibitor to identify and treat vasoconstrictor and volume factors in hypertensive patients. New Engl J Med 291: 817, 1974

9. Blumberg AL, Denny SE, Marshall GR, Needleman P: Blood vessel-hormone interaction: angiotensin, bradykinin and prostaglandins. Am $\mathrm{J}$ Physiol 232: $\mathrm{H}$ 305, 1977

10. Blair-West JR, Coghlan JP, Denton DA et al: Effects of prostaglandin $\mathbf{F}_{1}$ upon the steroid secretion of the adrenal of the sodium deficient sheep. Endocrinology 88: 367, 1971 
11. Saruta T, Kaplan NM: Adrenocortical steroidogenesis: The effects of prostaglandins. J Clin Invest 51: 2246, 1972

12. Beaty O III, Sloop CH, Schmid HE et al: Renin response and angiotensinogen control during graded hemorrhage and shock in the dog. Am J Physiol 231: 1300, 1976

13. Case DB, Wallace JM, Keim HJ et al: Possible role of renin in hypertension as suggested by renin-sodium profiling and inhibition of converting cnzyme. New Engl J Med 296: 641, 1977

14. Curtiss C, Cohn JN, Vrobel T, Franciosa JA: Role of the renin-angiotensin system in the systemic vasoconstriction of chronic congestive heart failure. Circulation 58: 763, 1978

15. Marthy VS, Waldron TL, Goldberg ME: The mechanism of bradykinin potentiation after inhibition of angiotensin-converting enzyme by SQ 14225 in conscious rabbits. Circulat Res 43 (suppl I): I-40, 1978

16. Cody RJ, Tarazi RC, Bravo EL, Fouad FM: Hemodynamics of orally-active converting enzyme inhibitor (SQ 14225) in hypertensive patients. Clin Sci Mol Med 55: 453, 1978

17. de Freitas FM, Farasco EZ, de Azevedo DF: General circulatory alteration induced by intravenous infusion of synthetic bradykinin in man. Circulation 29: 66, 1964

18. Armstrong JM, Dusting GJ, Moncada S, Vane JR: Cardiovascular actions of prostacyclin $\left(\mathrm{PGI}_{2}\right)$, a metabolite of arachidonic acid which is synthesized by blood vessels. Circulat Res 43 (suppl I): I-112, 1978 